Article

\title{
Paradise Islands? Island States and Environmental Performance
}

\author{
Sverker C. Jagers, Marina Povitkina, Martin Sjöstedt and Aksel Sundström * \\ Department of Political Science, University of Gothenburg, Gothenburg 40530, Sweden; \\ sverker.jagers@pol.gu.se (S.C.J.); marina.povitkina@gu.se (M.P.); martin.sjostedt@pol.gu.se (M.S.) \\ * Corresponding: aksel.sundstrom@pol.gu.se; Tel.: 46-31-786-1607
}

Academic Editor: Thomas A. Trabold

Received: 23 October 2015; Accepted: 16 March 2016; Published: 19 March 2016

\begin{abstract}
Island states have been shown to outperform continental states on a number of large-scale coordination-related outcomes, such as levels of democracy and institutional quality. The argument developed and tested in this article contends that the same kind of logic may apply to islands' environmental performance, too. However, the empirical analysis shows mixed results. Among the 105 environmental outcomes that we analyzed, being an island only has a positive impact on 20 of them. For example, island states tend to outcompete continental states with respect to several indicators related to water quality but not in aspects related to biodiversity, protected areas, or environmental regulations. In addition, the causal factors previously suggested to make islands outperform continental states in terms of coordination have weak explanatory power in predicting islands' environmental performance. We conclude the paper by discussing how these interesting findings can be further explored.
\end{abstract}

Keywords: island states; environmental performance; democracy; institutional quality

\section{Introduction}

The overall objective of the article is to investigate if island states have better environmental performance than continental states, and if so, to further explore why this can be the case.

We are witnessing an increased suffering from environmental degradation, including climate change, overfishing, deforestation, and biodiversity loss [1]. Scholars have argued that sustainable management of natural resources requires collective action-where a sufficient amount of actors cooperate, as opposed to defecting [2]. However, the well-known puzzle is that it often seems rational not to take part in any collective action [3]. This means that the overcoming of these various challenges requires some kind of intentional coordination [4]. While the social sciences have made progress in understanding the group-level conditions under which such coordination come about [2,5], we have gathered far less systematic knowledge about the conditions under which large-scale coordination occurs [6]. Yet, what we do know is that large-scale challenges are far more demanding since they require coordination of actions both between and within nations, organizations, authorities, companies, and larger groups of individuals [7]. Moreover, large-scale coordination problems tend to be characterized by temporal delays and spatial separation between the relevant actions and their consequences, as well as uncertainty about how actions affect the resource or good in question [8]. Regardless, whether referring to voluntary or regulated (coordinated) collective action, the prospects for achieving successful cooperation are, of course, much smaller under such circumstances. Nonetheless, there are examples of actors making unilateral contributions, for example, reducing their carbon dioxide emissions, as well as examples of when coordination problems have, in fact, been more or less solved, as in the case of the Montreal Protocol (which successfully reduced the production of chlorofluorocarbons) [9]. 
We suggest that one fruitful way to advance this literature may be to conduct more systematic studies of successful nations in regard to larger-scale coordination. To come to grip with this task we, therefore, focus on island states. We have three reasons for this approach: first, it is often asserted that island states are more successful compared to continental states in coordinating the provision of a variety of social goods, such as democracy, economic development, and rule of law [10-12]. Second, international policy discussions have recently focused explicitly on island states and their assumed progress in also coordinating natural resources; for instance, the need to protect the rich biodiversity of island states $[13,14]$ and-as stated in the declaration from the World Summit on Sustainable Development in 2002 - that island states "continue to take the lead in the path towards sustainable development" [15] (p. 41). Third, it has also been suggested that successful coordination in respect to natural resource management is facilitated by many of the factors typically characterizing island states, such as their size and remoteness, as will be discussed below [16-19]. Yet, to this date, no study has systematically investigated the general environmental performance of island states in a comparative perspective. In this paper, we follow the previous authors' approach [12] in focusing on islands states, in general, and analyze a sample containing nations from both the group of small island developing states (SIDS) and islands states. This choice is motivated since we are interested in investigating, for instance, if size matters for islands' environmental performance. To examine this feature, and other explanatory factors, we need the full variation present in the sample of all island states. Thus, our sample is quite heterogeneous and includes, for instance, prosperous islands states as well as low-income ones, but we believe this choice is uncontroversial and the standard procedure in comparative cross-country research.

In these rather explorative endeavors, we pose two questions for research. First, do island states, on average, have better environmental performance than continental states? By investigating island states' environmental performance, we refer to both quality and availability of various natural resources, such as water, air, forest, biodiversity, as well as actions aimed at improving the environment (for example, signing of international treaties and regulations) $[17,20]$. Having identified the specific areas in which island states appear to perform better, we then pose the second question: can the factors identified as explanations for island states' relative success with regard to political and economic development also explain islands' success in respect to their environmental performance in the identified areas? To investigate these questions empirically, we first make a systematic comparison of how well island states and continental states perform in regard to different environmental indicators, measured on the national level. We utilize a dataset on environmental indicators that consists of 105 different measures collected from what are commonly considered reliable sources, available across nations. As such, this article uses, to our knowledge, a comprehensive set of data on environmental indicators available, enabling us to find out if island states' general propensity to act collectively is also present in the case of environmental performance, such as provision of clean water, protection of forests, and protection of biodiversity. We believe that this large- $n$ approach, though losing some nuances present in qualitative studies, has important advantages. For example, it enables us to discover general patterns and, hence, address our research question. Second, we narrow down our focus by selecting those environmental indicators where being an island state, on average, tends to have a positive effect and we continue by investigating what factors seem to be driving these results. While there is, possibly, a rather large distance between the two concepts that we wish to examine-being an island state on the one hand and achieving successful environmental performance on the other-we believe that the exploratory nature of this paper warrants such an approach.

The paper is organized as follows. In the next section, we review previous research on the characteristics that have previously been argued to explain why island states outperform continental states in numerous regards. The subsequent section accounts for the methods and data. The result section is then organized according to the two-fold aim. The article concludes with a critical examination of how these results can be taken forward in future research. 


\section{Island States and Environmental Performance}

\subsection{Defining Island States}

While island states have been defined as "states that are islands, part of an island or consist of islands and part of islands" [21] (p. 702), we will refer to a stricter definition, that is, "a country with no land borders" [12] (p. 36), since it assumes that a country's government is responsible for taking care of the whole territory surrounded by water and is fully accountable for the environmental outcomes of the island. (The full list of island states analyzed in this paper is available in Appendix A. Following the approach of Congdon-Fors [12], we treat Cuba as an island state-though a small part of its border is constituted of Guantanamo Bay-and do not treat Australia as a country, but a continent.) To illustrate the implication of this definition, the Dominican Republic is not seen in this study as island state, since the situation on Hispaniola — the island the country is located on-is also determined by outcomes in Haiti, which shares the same land mass. Hence, it is not one polity alone that is responsible for the environmental health on that island. Having said that, we acknowledge that island states are not a homogenous category, but rather comprise a diversity of nations. For instance, they differ tremendously in political system, history, population, and size. They have different topography: some are coral islands, while others are volcanic; some of them are archipelagos, while others are single-island states. What unites them, however, is their isolation and vulnerability, dependency on foreign trade, and full accountability for environmental outcomes of their territories. Importantly, our focus is not on a rather broadly-defined category of small island developing states (SIDS), which also includes continental states, but rather on all independent states that have no land borders, which we define as islands.

\subsection{Island States Characteristics}

A rather large literature in geography and economics has argued that island states suffer from their smallness and isolation, two factors often characterizing such states (this is not to say that we only focus on small nations). For example, scholars have argued that a public goods provision has increasing returns to scale and, hence, small states suffer from higher per capita costs of public goods [22-25]. Small states may also face disadvantages in terms of diversifying their production, having a limited labor force and facing difficulties in recruiting high-quality candidates [11,26]. In addition, they are thought to suffer from their remoteness, having high transportation costs, small internal markets, and a high degree of vulnerability to economic shocks and natural disasters [27].

However, recent studies largely turn these expectations on their head because, small states-and island states in particular-are shown to outperform continental states on a number of institutional indicators and collective-action-related outcomes. On average, they have both higher income and productivity levels. They perform well on indices of civil and political rights; they have provided bases for vibrant civil societies, compared to continental states $[15,28]$ and they tend to have stronger institutions in terms of democracy, plurality elections, and rule of law $[10,29]$. How can this be understood? The literature, finding a positive effect from smallness, and "islandness" in particular, suggests a number of causal mechanisms producing such beneficial outcomes.

First, a common argument is that islands tend to be more ethnically and linguistically homogenous [30]. Homogeneity is in turn said to facilitate collective action by giving citizens "a high degree of sympathetic identification with each other" and resulting in "a greater effort to feel others out" [31] (p. 222). The sense of community and cohesiveness found in island nations is, consequently, held to reduce the risk of conflict and stimulates the development of exchange, high-quality institutions, and economic productivity. The shared interests, intimacy, and identity of island populations have also been interpreted in terms of social capital, in which islands are prone to foster a sense of national identity that is stronger than group identity. Accordingly, island states have a distinct sense of place which, in turn, may lead to a sense of unitarism and a better ability to accumulate national-level social capital as opposed to group-level social capital [32] (p. 35). It should be noted that there are, 
in fact, striking examples contradicting such claims of heterogeneity. For example, the small island state Mauritius is one of the most ethnically heterogeneous states in the world and yet performs extraordinarily well in terms of economic and social development [33].

The second mechanism said to work in favor of positive developments in island states is their distinct colonial history. Island states are, in this discussion, held to have experienced a comparatively deep penetration of colonialism, and British and Christian influences in particular. As claimed by some [30], due to the fact that pre-imperial societies were less prevalent on most of the islands, this deep penetration was, in turn, not perceived as a foreign import challenging pre-existing values or established modes of political organization. Hence, the transplantation of institutions from the colonizer to the colony was much more effective and non-upsetting in island states. On islands democratic values have, thus, penetrated the citizenry to a larger extent than in continental colonies. Although colonialism brought slavery and oppression, as elsewhere in the world, the fact that the citizens of islands in many cases are descendants of slaves has also been argued to further stimulate such anti-authoritarian tendencies [34]. Finally, the deep penetration of colonialism is said to have been facilitated by geographically-determined borders, which made the borders less contested [33].

Third, the fact that the island borders are given by nature is also a commonly-maintained mechanism explaining island states' outstanding performance in terms of political and social organization. More specifically, the natural barrier formed by the water surrounding islands has been said to reduce governments' investments in security. The geographic features of islands imply both that the incentives for a ruler to expand its territory and the de facto risk of getting invaded or embroiled in warfare are significantly reduced [12]. Islands are, hence, argued to be sheltered from conflict and the resulting lack of incentives to build up a strong military facilitates the decentralization of power conducive to the development of high-quality institutions, accountability, and responsiveness [30]. In addition, because of the small jurisdictions, the cost of internal conflicts is thought to be higher on islands than in continental states which, in turn, promotes the development of a basic consensus of values [35]. Island inhabitants simply "must get along with each other" and for that reason develop "sophisticated modes of accommodation" [36] (pp. 38-39), or strategies for "managed intimacy" ([37] (p. 21); see also [33]).

The fourth mechanism is size. Islands tend to be relatively small in comparison to continental states-and the number of island states increases exponentially with decreasing land size. In several studies the small size of island states' polity is said to bring a number of advantages. For example, smallness implies that there are more opportunities for interactions between the ruler and the ruled and such accessibility to the political system is generally perceived as encouraging citizen participation. Smallness per definition implies that there are fewer layers of political organization, and this, in turn, is expected to facilitate transparency and open channels of communication, which have positive effects on accountability and responsiveness on the part of governments [38]. The leaders may also more easily acquire information about the preferences and needs of their citizens, leading to greater government efficiency and potentially a higher quality of government [12]. Anckar also argues that while small units may be as categorically heterogeneous as larger polities, their citizens tend to develop uniformity in attitudes and values [38]. This line of reasoning fleshes out Etro's claim that the inhabitants of small countries tend to more easily agree on a higher provision of public goods [39]. In sum, smallness is, according to this logic, expected to foster "highly personalized and transparent societies" [37], (pp. 38-39). However, a small geographical area and a small population size not only affect the relationship between the ruler and the ruled, but they also facilitate interaction within the populace. That is, since small-scale social structures tend to be personal and informal, interactions on all levels have a comparatively cooperative character (we are, however, aware of the fact that not all island states are small.)

The fifth and final mechanism focuses on aspects interchangeably referred to as remoteness, peripherality, or isolation. Ott argues that island elites, in general, tend to be more cooperative in their interactions, while citizens, in their turn, tend to imitate this behavior [29]. Remoteness, peripherality, 
and isolation are, hence, expected to play a unifying role as inhabitants of remote locations face special problems, shared by all members of the community, which are thought to result in a shared frame of reference; $c f$. [12,38]. Remoteness and isolation thus facilitate homogeneity and cooperation since the links between self-interest and the interests of the nation are more obvious [31]. More specifically, the geographic precision of island states facilitates unitarism and forms a shared national identity, which can explain island states' comparative success in terms of political and social development [40].

Given the reviewed literature we identify five features that have been brought forward to explain why island states might perform better than continental states in collective-action-related outcomes. In sum, when answering our second research question regarding which are the major factors explaining small islands' relative success in environmental performance, the following five factors will be included in the analysis:

- Homogeneity

- Colonial heritage

- Geographical characteristics

- Size

- Isolation

\subsection{Island States Characteristics and Environmental Performance of Island States}

What bearing do these findings and arguments have on nations' environmental performance? Partly contrary to popular belief and previous theoretical expectations, the reviewed literature essentially shows that island states have several comparative advantages that may promote cooperation and, ultimately, the achievement of social, political, and economic development. Due to similarities in inducements for collective action between different social goods it is, thus, reasonable to assume that (and investigate if) the same kind of logic being accounted for applies also to environmental performance. However, there are also critical reservations in this literature, pinpointing that certain characteristics of island states may, in fact, create disincentives for collective action that could have implications for environmental performance.

Theories about social, political, and economic development emphasize a number of collective-action-related factors and social dilemmas that are equally at the core of theories about environmental performance. For example, it is a well-known fact that sustainable management of natural resources depends fundamentally on the extent to which resource users expect other resource users to act sustainably. Intuitively, it would be in each citizen's interest not to overuse natural resources. However, as deteriorating conditions of many resource systems indicate, natural resources have certain characteristics that make all resource users believe that others overharvest the resource, thus engaging in overuse themselves [41]. This leads to the tragedy of the commons, also known as a collective action dilemma, prisoner's dilemma, or a social trap [40,42,43]. In such a situation "horizontal expectations that other resource users will embark on a non-cooperative path and free ride on conservation efforts make every individual reluctant to participate in conserving the collective good or employing a cooperative strategy themselves" [44] (p. 618). Hence, theory suggests that social capital — the standard measure of people's tendency to cooperate—should be beneficial for nations' environmental performance $[17,45]$. Several of the causal mechanisms analyzed in the literature on the islands' performance have, in fact, been previously attributed as factors facilitating successful cooperation among individuals in natural resource management. For instance, the argument about size (both of the country and of the population) has been brought up when discussing the impact of group size on collective action outcomes in cooperation over common-pool resources. Accordingly, smaller groups will, on average, be more prone to cooperate as this feature facilitates coordination [16,46]. Similarly, heterogeneity has been shown to be a complex, yet important, factor for determining the outcomes in cooperation over natural resources [18,47]. As stated by Grafton and Knowles, "The 
greater the social divergence the lower is the opportunity for collective action that may help address environmental concerns" [17] (p. 340).

However, the natural resource management literature within the social sciences does not only emphasize the role of horizontal expectations. It also underlines that in order to fully understand the causes of overexploitation and poor resource management, there is a need to address state capacity and the vertical relationship between the government and resource users [44]. In addition to the analysis of local-level institutions, horizontal expectations and their effect on the behavioral strategy of resource users, it is necessary to pay attention to how these arrangements "interact with and (are) affected by the surrounding local and national institutions in which they are embedded or nested" ([44] (p. 618), see also [48-50]). As such, the issue of environmental performance can be considered an interesting exploration of further aspects of the performance of island states relative to continental states. The causal mechanisms reviewed earlier would certainly suggest an affirmative answer to such a query.

At the same time, however, there are probably reasons to be cautious about the causality and how the various mechanisms actually affect cooperative environmental behavior in the case of island states. From our point of view, one could equally twist the coin and argue that because of a number of other factors, we should rather expect negative outcomes when it comes to islands and environmental performance. For example, island states—and especially the SIDS-are often considered to be more vulnerable to economic, political, or environmental shocks [11,51]. Such concerns have evoked plenty of response in international policy in high-level conferences, for instance in the Agenda 21 and in the Rio Declaration, but also through the Program of Action for the Sustainable Development of Small Island Developing States [52]. As mentioned in the introduction, these discussions have recently focused explicitly on the rising threats to biodiversity in island states [13,14]. As such, the year 2014 was named the "International Year of Small Island Developing States" by the United Nations, where one of the outspoken aims was to create awareness about the unique, and often vulnerable, environment on island states [15]. In terms of the economy, island states are expected to suffer from greater output volatility and greater volatility in terms of trade, which might spur more intense resource exploitation. Overexploitation of resources may lead to severe and sometimes irreversible environmental damage, as the stories of Easter Island and Pitcairn show [52]. It has also been pointed out that the lack of diversity in the productive base of island states' economies can be assumed to have negative effects on their resilience to disasters [51]. Moreover, from a political point of view, the flipside of the benefits from the personal and informal character of political interaction previously described is that small polities might also be more vulnerable to nepotism, cronyism, patronage, and political clientelism [29,33,53], which can be expected to have clear-cut negative effects on environmental management. As recently shown by Veenendaal, a qualitative study of four microstates, three of which are islands, suggests that smallness can be detrimental for democracy [54]. Finally, since islands tend to be located in geographic areas where hurricanes and typhoons are common, they can also be expected to be more vulnerable to environmental shocks in the form of natural disasters.

In light of possible negative consequences of being an island on collective-action-related outcomes, studying islands' environmental performance in a comparative perspective is even more interesting. If any positive effects from our explanatory factors are found, their impact on environmental performance, in reality, must be even stronger to counteract the possible negative effects.

Bearing these critical reservations in mind, we now continue our exploratory endeavors of empirically investigating whether or not islands outperform continental states when it comes to the environment and if so, what may be the driving forces behind this. In the next section we account for the data and methods that we have used and how our dependent and independent variables are made operational. 


\section{Method and Data Description}

Our empirical strategy consists of two parts. First, we identify and evaluate the environmental indicators in which island states fare better than other states. Using bivariate regression analysis on a large number of environmental indicators across countries, we find a number of environmental outcomes in which island states on average seem to do better than continental states. Second, we then investigate why this is so. We analyze the indicators where islands perform better in order to investigate what factors seem to drive this relationship. We test the possible hypotheses derived from the literature and draw inferences regarding which factors seem to explain the relative success of island states in these environmental outcomes.

\subsection{Dependent Variables/Indicator Selection}

It is inherently difficult to operationalize nations' environmental performance into empirical measures with high content validity. As is known and widely discussed among scholars addressing this concept, it is difficult to capture the environmental performance of states in quantitative measurements (see $[55,56])$. As stated by Duit and colleagues, "A problem confronting most studies aiming to compare environmental management performance among countries is that of finding valid estimates of environmental quality" [45] (p. 43). However, there are numerous attempts to quantify states' environmental performance. The scholarly community and policymakers have increasingly made environmental indicators available in recent decades, measuring various aspects of national-level environmental performance $[57,58]$. These measurements vary from aggregate indices, such as the yearly Environmental Protection Index, where a country receives a score based on outcomes in numerous environmental aspects, to specific data on particular measures such as levels of a certain pollutant. A strategy to analyze a nation's environmental performance is hence to study its position in such indices [17]. Yet, when scholars assess countries' environmental performances they often only focus on single environmental indicators $[59,60]$. It has been identified that this is a serious threat to the inferences drawn about the various factors affecting the environmental performance of states [61].

In order to meet the challenging task of operationalizing the truly multifaceted notion of environmental performance we adopt a rather ambitious approach. To capture this concept in its widest possible sense, we use a unique data set where we have compiled all environmental indicators available for large cross-country comparisons deemed to reflect the state of the environment. More specifically, this dataset consists of 105 variables available across countries, capturing different aspects of environmental performance, including both indicators related to quality and quantity of natural resources (such as water, air, forest, fisheries, etc.) and actions aimed at improving the environment (for example, signing of international treaties and regulations). We collected the indicators according to two criteria: (1) if indicators measure aspects of states' environmental performance and (2) if they are available across a large sample of countries. Specifically, our criteria included only those indicators that had data for at least 10 island states in order to get a comparable sample. With these principles in mind we collected the final number of indicators from various sources. We utilized existing sources containing a large number of indicators available to the public, for example, the United Nations' GEO online database and the Quality of Government dataset. Yet, we have found that no existing overview of environmental indicators captures the full availability of measures for states' environmental performances. The dataset we compiled is, thus, to our knowledge, the most comprehensive overview of environmental indicators available across a global sample of countries and commonly used by scholars in various disciplines (for example, see [17,57]). Table 1 summarizes the areas of environmental performance covered by the indicators used in our analysis. 
Table 1. List of the areas covered by the selected environmental performance indicators.

\begin{tabular}{c}
\hline Water quality and access to water and sanitation \\
Air quality \\
Biodiversity \\
Protected areas \\
Forest and vegetation \\
Fisheries and the marine environment \\
Energy \\
Waste \\
Soil degradation and land use \\
Ecological footprint \\
Other anthropogenic pressure \\
Environmental regulation \\
\hline
\end{tabular}

The result is a data set of 105 indicators where the unit of analysis is countries. For a detailed overview of this data refer to Supplementary Material. When choosing environmental indicators, our aim was to capture the full variation of the measurements addressing the fact that environmental performance is a diverse concept [61]. Therefore, we used the elementary parts of environmental indices, choosing indicators as specific as possible. For example, the Environmental Performance Index is an aggregate score but consists of a number of subcomponents. We, therefore, only study the elementary parts of this index and not the built-up measurement in itself. Following the same logic, we avoided compiling different measurements into a larger index.

When collecting the data, we found indicators from different sources essentially quantifying the same concept. For example, several sources estimate national carbon dioxide emissions. In these instances we have selected the indicator covering the largest number of states. For a full list of environmental indicators being used as dependent variables in the first part of our empirical analysis, see Appendix B and see Supplementary Materials for a more detailed overview of the indicators.

\subsection{Independent Variables}

In the second stage of our analysis we focus on the indices in which island states, on average, seem to do better than continental countries and set out to test the explanatory power of the causal mechanisms discussed in previous literature on the performance of small island states. These factors are derived from the theoretical literature discussed above and are operationalized according to the following logic: Population size is a measure of the number of people (thousands) per each nation. The figures refer to the year 2005 and are taken from the United Nations Population Division through the Compendium of Environmental Sustainability Indicators [62]. Isolation is the distance (kilometers) from the nearest continent. If a country is within a continent it is assigned the value zero. The figures are taken from the Environmental Vulnerability Index [63]. Homogeneity is measured with the ethnic fractionalization variable. This indicator reflects the probability that two randomly selected people from a given country will not belong to the same linguistic or religious group. The higher the number in this indicator, the more fractionalized society is. The indicator is developed by Alesina and colleagues [64]. Total area is a variable expressed in squared kilometers and refers to a nation's total area. The data are obtained from the CIA World Factbook [65]. Conflicts are measured with a variable expressed in the average number of conflict years per decade within the country over the past 50 years. This variable intends to gauge one of the aspects of homogeneity, discussed in the theory section. The data are taken from Environmental Vulnerability Index [63], based on estimates from International Disaster Database [66]. Colonial heritage is a dummy variable, assigning the value 1 if the country has ever been a British colony. We included it, as British colonies have previously been found to develop better political institutions than former territories of other colonial powers [30]. These data are taken from Teorell and Hadenius (2005) [67]. Island is a dummy variable measuring if the country is an island (assigned 1). 


\subsection{Method}

In the first part of the analysis, the aim is to compare performance of island states to the rest of the world in our chosen 105 environmental outcomes. To fulfill this purpose we run separate bivariate ordinary least squares (OLS) regressions for all the environmental indicators and use the island dummy as an independent variable to determine statistically whether island status is associated with better performance in the chosen indicators. Using dichotomous variables, where island status is coded as 1 and the rest of the countries as 0 , allows us to compare environmental outcomes in these two categories in the regression analysis. As we will discuss below, this renders a sample of 20 environmental indicators where we find positive effects from our island dummy variable. Regarding our numerous dependent variables, we took effort to investigate their individual dispersion. Six of our dependent variables (acidification exceedance from anthropogenic sulfur deposition, fish catch, generation of hazardous waste, and water footprint of production for blue water, green water, and return flows) were logarithmically transformed for a better model fit. When heteroskedasticity of errors was detected through Breusch-Pagan/Cook-Weisberg heteroskedasticity test, robust standard errors were added to correct for it.

In the second part of the analysis we focus on these 20 environmental indicators in which island status has a positive effect. The aim of the analysis is to determine which of the six independent variables discussed above - that is, population size, ethnic fractionalization (homogeneity), colonial heritage, conflicts, total land area, and isolation-can explain the islands' better performance in these 20 different indicators. In order to test what drives such results, we create interaction terms between an island dummy variable and each of the six explanatory factors. The reason for doing so is to create an estimate for the coefficients of each variable that is contingent on whether a country is an island or not. For instance, the interaction effect between the size of a country and the island dummy variable allows us to investigate if the positive effects on an environmental indicator from being an island stem from its size. We then use OLS regression analysis to examine the explanatory power of these interactions for each of the 20 dependent variables where islands perform better. Here we checked for a normal distribution of residuals and made sure, where needed, to transform the highly skewed independent variables - area and population size-to improve the residuals. The analysis of both raw data and the data corrected for normal distribution was performed and the model with normal distribution of residuals and higher explanatory power was chosen.

OLS is a suitable method as our dependent variables are on neither binary nor ordinal scales [68]. It allows us to analyze large number of countries while using aggregate data for each nation. In employing ordinary least squares regression for studying island states, we follow the methodology used by Dag Anckar and Heather Congdon-Fors [10,12,64]. We use STATA 12 software (http:/ / www.stata.com/, StataCorp LP, College Station, TX, USA) for conducting this analysis.

\section{Results and Discussion}

\subsection{Environmental Performance of Island States}

In the first step of our analysis we investigate the 105 environmental indicators to determine those in which island states on average seem to do better in than continental states. Using OLS regression analysis we find that there is a large variance between the performances of island states across the different environmental indicators. On some indices the dummy variable measure of island status has a significant and positive impact. However, for the majority of the indices analyzed we find no significant effect from island status. Moreover, we even find a significantly negative effect from being an island on a number of the environmental indicators. The environmental indices in which islands on average perform better than continental states are listed in Table B1 in Appendix B. The environmental indices where island status have a negative effect are reported in Table B2, while Table B3 reports the indices where we find no significant effect from the dummy measure of being an island state (as the results tables are rather lengthy due to the large number of dependent variables, here we only 
report the summary of the results: the direction of the relationships and their significance. The tables reporting coefficients and standard errors of this exploratory first step are available upon request). These counter-intuitive results can be exemplified. Consider, for instance, that in the indicator Coastal shelf fishing pressure-measuring sustainability in fisheries-a majority of the 20 countries with the most sustainable fishing practices are island states. However, the reverse pattern is true for several measures. For example, in the indicator Threatened mammal species, a majority of the 20 states with the highest number of endangered mammals are in fact island states.

More specifically, analyzing the results reported in Tables B1-3 we find that being an island has a significant positive impact in only 20 of our 105 environmental indicators. Island states seem to perform worse than continental states on average in 31 indicators in the analysis. However, in a majority of the indicators, 54 out of the total 105, island status does not have a statistically significant impact. Hence, this is the first important finding of this paper: the positive effect from being an island on the performance in the environmental indicators is far from a general one. In fact, in most of the indicators, we find no such effect.

Judging from the first analysis, are there trends that lead us to infer that islands tend to perform better in a certain type of environmental outcomes? Overall, the results are diverse and the patterns are far from clear-cut. However, we find some trends in the bivariate results that might be worth exploring further. Judging from Table B1 in Appendix B, it seems that there is a positive effect from being an island on several indices related to water quality and fisheries. Inversely, islands seem to do worse in other groups of environmental indicators, for example, indicators related to protected areas and biodiversity. Additionally, on measurements gauging environmental regulations, island status seems to actually have a negative effect.

It should be noted that a focus on the exact number of indicators could be misleading here. In our analysis some environmental features are only measured by a few indicators, such as greenhouse gas emissions, measured by the national levels of carbon dioxide emissions; other aspects of environmental performance are estimated by several indicators. For instance, the detailed availability of data on biodiversity renders a more nuanced analysis of such indicators as threatened mammal species, bird species, amphibian species, etc. Hence, the large number of indicators for a certain concept might skew the general results if only analyzed in numerical terms. As mentioned before, we were careful not to include indicators that measure identical concepts. However, this concern begs us to be cautious when making an inference of the general pattern found in this analysis, but as a general pattern, the dummy measure of being an island state still has a significantly negative effect or no effect at all on far more indices than it has a significantly positive effect.

\subsection{The Impact from Our Independent Variables on the Indices Where Islands Perform Better}

In the second part of our empirical analysis we analyze the 20 environmental indicators in which island status has a significantly positive effect (see Table B1 in Appendix B). The aim is to assess the extent to which the five factors (homogeneity, colonial heritage, total land area, population size, and isolation), suggested in the literature as beneficial characteristics of islands (measured in the six indicators discussed above), can explain their good performance in these environmental indices. Hence, we are not interested in the impact from these characteristics on the indices in general, but specifically if they matter for the performance of island states. As mentioned we, therefore, model interaction terms between the island dummy variable and each of the six independent indicators to see what features seem to drive the results from the positive effect of being an island on the 20 environmental indices where islands perform better.

The results from the multivariate regression analysis, reported in Table 2 elucidate that the six variables we use as independent variables have little explanatory power for why island states perform better in these indices. 
Table 2. The effect of island-specific factors on selected environmental outcomes, OLS regression analysis

\begin{tabular}{|c|c|c|c|c|c|c|c|c|c|c|c|}
\hline & $\begin{array}{l}\text { Access to } \\
\text { Water }\end{array}$ & $\begin{array}{l}\text { Access to } \\
\text { Sanitation }\end{array}$ & $\begin{array}{c}\text { Water } \\
\text { Quality }\end{array}$ & $\begin{array}{c}\text { Water } \\
\text { Consumption }\end{array}$ & $\begin{array}{c}\text { Nitrogen } \\
\text { Loading }\end{array}$ & $\begin{array}{c}\text { Urban } \\
\text { Particulates }\end{array}$ & Acidification & $\begin{array}{c}\mathrm{CO}_{2} \text { per } \\
\text { GDP }\end{array}$ & $\begin{array}{l}\text { Threatened } \\
\text { Ecoregions }\end{array}$ & $\begin{array}{c}\text { Forest Cover } \\
\text { Change }\end{array}$ & $\begin{array}{c}\text { Timber } \\
\text { Harvest Rate }\end{array}$ \\
\hline $\begin{array}{l}\text { Interpretation of the DV, direct: an } \\
\text { increase is interpreted as "good" for the } \\
\text { environment, inverse: an increase is } \\
\text { interpreted as "bad" for the environment. }\end{array}$ & direct & direct & direct & direct & direct & direct & Inverse & direct & inverse & direct & direct \\
\hline \multirow[t]{2}{*}{ Interaction, islands-Isolation } & 0.040 & 0.029 & -0.023 & -0.605 & -0.001 & -0.013 & 0.001 & -1.665 & -0.012 & 0.035 & 0.023 \\
\hline & $(0.022)$ & $(0.026)$ & $(0.019)$ & $(4.025)$ & $(0.007)$ & $(0.007)$ & $(0.001)$ & (2.195) & $(0.027)$ & $(0.028)$ & $(0.033)$ \\
\hline Interaction, islands-Area & $\begin{array}{c}0.787 \\
(4.056)\end{array}$ & $\begin{array}{l}3.390 \\
(5.735)\end{array}$ & $\begin{array}{c}3.680 \\
(3.409)\end{array}$ & $\begin{array}{l}244.400 \\
(710.000)\end{array}$ & $\begin{array}{l}6.308^{* *} \\
(2.333)\end{array}$ & $\begin{array}{c}0.000 \\
(0.000)\end{array}$ & $\begin{array}{c}0.216 \\
(0.127)\end{array}$ & $\begin{array}{r}552.300 \\
(313100)\end{array}$ & $\begin{array}{l}9.963^{*} \\
(4.851)\end{array}$ & $\begin{array}{c}2.399 \\
(5.410)\end{array}$ & -2.200 \\
\hline \multirow[t]{2}{*}{ Interaction, islands-Ethnic fract. } & 0.408 & -10.110 & -37.820 & -4.833 & 3.243 & 6.554 & $\begin{array}{l}(0.127) \\
0.726\end{array}$ & $-5.618^{*}$ & -18.220 & 24.300 & -9.014 \\
\hline & $(25.450)$ & $(26.420)$ & $(24.030)$ & $(4.090)$ & $(8.187)$ & $(16.090)$ & $(0.935)$ & $(2.371)$ & $(30.740)$ & $(32.630)$ & $(9.596)$ \\
\hline Interaction, islands-Population & $\begin{array}{l}1.571 \\
(5.246)\end{array}$ & $\begin{array}{l}-0.340 \\
(5.926)\end{array}$ & $\begin{array}{l}-2.394 \\
(3.082)\end{array}$ & $\begin{array}{l}-90.330 \\
(850.400)\end{array}$ & $\begin{array}{l}-2.907 \\
(2.834)\end{array}$ & $\begin{array}{l}0.000 \\
(0.000)\end{array}$ & $\begin{array}{l}-0.270 \\
(0.229)\end{array}$ & $\begin{array}{l}-30.490 \\
(397.500)\end{array}$ & $\begin{array}{l}-6.726 \\
(6.404)\end{array}$ & $\begin{array}{l}-3.450 \\
(6.736)\end{array}$ & $\begin{array}{r}2.460 \\
(2.338)\end{array}$ \\
\hline \multirow[t]{2}{*}{ Interaction, islands-Conflicts } & 0.004 & 0.110 & -0.103 & -8.015 & 0.219 & -0.322 & 0.010 & -107.300 & 3.011 & 0.472 & 0.252 \\
\hline & $(1.783)$ & $(1.133)$ & $(0.875)$ & $(246.000)$ & $(0.567)$ & $(0.953)$ & $(0.063)$ & (103.700) & $(2.218)$ & $(2.293)$ & $(0.672)$ \\
\hline Interaction, islands-British & $\begin{array}{c}4.797 \\
(12.220)\end{array}$ & $\begin{array}{l}31.820^{*} \\
(14.130)\end{array}$ & $\begin{array}{c}6.368 \\
(13.540)\end{array}$ & $\begin{array}{l}1.823 \\
(2.317)\end{array}$ & $\begin{array}{l}-3.657 \\
(4.492)\end{array}$ & $\begin{array}{c}0.426 \\
(8.133)\end{array}$ & $\begin{array}{c}0.496 \\
(0.350)\end{array}$ & $\begin{array}{c}-156.100 \\
(1.125)\end{array}$ & $\begin{array}{l}-10.290 \\
(14.860)\end{array}$ & $\begin{array}{c}6.203 \\
(16.170)\end{array}$ & $\begin{array}{c}2.065 \\
(6.753)\end{array}$ \\
\hline \multirow[t]{2}{*}{ Island dummy } & -27.090 & -38.710 & -8.811 & -121.100 & $-42.580^{* *}$ & 9.884 & -1.536 & -2.383 & -50.040 & -8.053 & 13.050 \\
\hline & (32.820) & $(42.450)$ & $(28.520)$ & $(6.916)$ & $(16.050)$ & $(7.653)$ & $(1.032)$ & $(3.006)$ & $(36.290)$ & $(41.150)$ & $(14.810)$ \\
\hline \multirow[t]{2}{*}{ Isolation } & $-0.045^{*}$ & -0.040 & 0.033 & 1.440 & 0.002 & $0.019^{* *}$ & -0.001 & 1.785 & 0.003 & -0.032 & -0.022 \\
\hline & $(0.021)$ & $(0.025)$ & $(0.018)$ & $(3.813)$ & $(0.007)$ & $(0.007)$ & $(0.001)$ & (2.178) & $(0.026)$ & $(0.027)$ & $(0.033)$ \\
\hline \multirow[t]{2}{*}{ Area } & $-5.768^{* *}$ & -4.242 & 2.543 & -442.900 & $-6.487^{* *}$ & 0.000 & $-0.298^{* *}$ & -233.700 & $-15.850^{* * *}$ & -4.065 & 1.789 \\
\hline & $(1.970)$ & (2.495) & $(1.357)$ & $(254.000)$ & $(2.331)$ & $(0.000)$ & $(0.104)$ & $(230.200)$ & (2.175) & $(2.507)$ & $(1.977)$ \\
\hline Ethnic fractionalization & $\begin{array}{c}-47.910 * * * \\
(10.020)\end{array}$ & $\begin{array}{l}-49.970 * * * \\
(11.770)\end{array}$ & $\begin{array}{c}17.460^{*} \\
(6.987)\end{array}$ & $\begin{array}{c}1.657 \\
(1.278)\end{array}$ & $\begin{array}{l}-3.005 \\
(8.102)\end{array}$ & $\begin{array}{l}-4.492 \\
(9.487)\end{array}$ & $\begin{array}{c}-1.824^{* *} \\
(0.632)\end{array}$ & $\begin{array}{l}116.000 \\
(1.042)\end{array}$ & $\begin{array}{c}5.064 \\
(12.350)\end{array}$ & $\begin{array}{c}-33.800 * * \\
(12.950)\end{array}$ & $\begin{array}{c}8.227 \\
(9.295)\end{array}$ \\
\hline \multirow[t]{2}{*}{ Population } & 4.040 & 2.514 & $-7.150 * * *$ & -205.700 & 2.933 & 0.000 & $0.574^{* * * *}$ & 53.900 & $17.16^{* * *}$ & 1.717 & -2.575 \\
\hline & $(2.355)$ & (2.646) & $(1.615)$ & (299.800) & $(2.827)$ & $(0.000)$ & $(0.135)$ & (271.100) & $(2.886)$ & (3.024) & $(2.290)$ \\
\hline \multirow[t]{2}{*}{ Probability of conflict } & $-1.903^{* * *}$ & $-1.905^{* *}$ & 0.176 & 7.626 & -0.250 & $-1.307^{*}$ & $-0.098^{* *}$ & 11.900 & -0.692 & -0.269 & -0.894 \\
\hline & $(0.584)$ & $(0.604$ & $(0.409)$ & $(73.880)$ & $(0.563)$ & $(0.577)$ & $(0.037)$ & $(64.360)$ & $(0.727)$ & $(0.752)$ & $(0.517)$ \\
\hline \multirow[t]{2}{*}{ British colony } & -2.318 & -8.621 & -3.643 & -1.160 & 2.642 & -8.970 & $-0.734^{* *}$ & 197.600 & $-17.67^{*}$ & -8.049 & -6.540 \\
\hline & $(5.617)$ & (6.119) & (3.917) & (721.700) & $(4.445)$ & $(5.853)$ & $(0.282)$ & $(529.600)$ & $(6.988)$ & $(7.299)$ & $(5.869)$ \\
\hline \multirow[t]{2}{*}{ Constant } & $117.100 * * *$ & $104.9^{* * *}$ & $62.25^{* * *}$ & $13.328 * * *$ & $143.400^{* * *}$ & $71.760^{* * *}$ & -0.743 & $7.904^{* * *}$ & $91.570^{* * *}$ & $120.100^{* * *}$ & $93.050^{* * *}$ \\
\hline & $(17.720)$ & $(24.140)$ & $(13.380)$ & $(2.356)$ & $(16.020)$ & $(4.564)$ & $(0.879)$ & $(1.978)$ & $(18.260)$ & $(21.650)$ & $(13.800)$ \\
\hline Observations & 175 & 173 & 173 & 159 & 159 & 165 & 184 & 169 & 183 & 178 & 157 \\
\hline R-squared & 0.349 & 0.336 & 0.351 & 0.136 & 0.137 & 0.178 & 0.308 & 0.077 & 0.377 & 0.158 & 0.100 \\
\hline Number of island states & 30 & 29 & 28 & 15 & 15 & 23 & 35 & 30 & 34 & 32 & 16 \\
\hline Robust standard errors & no & yes & yes & no & yes & yes & yes & yes & no & no & yes \\
\hline Population and area logged & yes & yes & yes & yes & yes & no & yes & yes & yes & yes & yes \\
\hline
\end{tabular}


Table 2. Cont.

\begin{tabular}{|c|c|c|c|c|c|c|c|c|c|}
\hline & $\begin{array}{l}\text { Fishing } \\
\text { Pressure }\end{array}$ & Overfishing & $\begin{array}{l}\text { Fish } \\
\text { Catch }\end{array}$ & $\begin{array}{l}\text { Clean } \\
\text { Waters }\end{array}$ & $\begin{array}{c}\text { Water Footprint } \\
\text { of Consumption } \\
\text { Internal }\end{array}$ & $\begin{array}{c}\text { Water Footprint of } \\
\text { Production-Green } \\
\text { Water } \\
\end{array}$ & $\begin{array}{c}\text { Water Footprint of } \\
\text { Production-Blue } \\
\text { Water }\end{array}$ & $\begin{array}{c}\text { Water Footprint of } \\
\text { Production-Return } \\
\text { Flows }\end{array}$ & $\begin{array}{c}\text { Generation of } \\
\text { Hazardous Waste }\end{array}$ \\
\hline $\begin{array}{l}\text { Interpretation of the } D V \text {, direct: an } \\
\text { increase is interpreted as "good" for the } \\
\text { environment, inverse: an increase is } \\
\text { interpreted as "bad" for the environment. }\end{array}$ & Direct & Direct & Inverse & Direct & Inverse & Inverse & Inverse & Inverse & Inverse \\
\hline Interaction, islands-Isolation & $\begin{array}{c}-0.027^{* *} \\
(0.009)\end{array}$ & $\begin{array}{l}-0.025 \\
(0.017)\end{array}$ & $\begin{array}{l}-0.001 \\
(0.001)\end{array}$ & $\begin{array}{c}0.018 \\
(0.010)\end{array}$ & $\begin{array}{c}0.205 \\
(0.552)\end{array}$ & $\begin{array}{c}0.000 \\
(0.002)\end{array}$ & $\begin{array}{c}0.001 \\
(0.003)\end{array}$ & $\begin{array}{c}0.001 \\
(0.002)\end{array}$ & $\begin{array}{l}-0.003 \\
(0.007)\end{array}$ \\
\hline Interaction, islands-Area & $\begin{array}{c}0.000 \\
(0.000)\end{array}$ & $\begin{array}{c}0.000 \\
(0.000)\end{array}$ & $\begin{array}{c}0.288 \\
(0.221)\end{array}$ & $\begin{array}{l}-2.930^{*} \\
(1.207)\end{array}$ & $\begin{array}{c}0.000 \\
(0.001)\end{array}$ & $\begin{array}{c}0.000 \\
(0.000)\end{array}$ & $\begin{array}{c}0.000 \\
(0.000)\end{array}$ & $\begin{array}{c}0.000 \\
(0.000)\end{array}$ & $\begin{array}{c}0.000 \\
(0.000)\end{array}$ \\
\hline Interaction, islands-Ethnic fract. & $\begin{array}{l}-3.492 \\
(25.070)\end{array}$ & $\begin{array}{c}2.847 \\
(22.970)\end{array}$ & $\begin{array}{l}-0.970 \\
(0.867)\end{array}$ & $\begin{array}{c}19.240 * * \\
(7.063)\end{array}$ & $\begin{array}{l}235.000 \\
(641.500)\end{array}$ & $\begin{array}{c}2.499 \\
(1.903)\end{array}$ & $\begin{array}{c}3.578 \\
(2.921)\end{array}$ & $\begin{array}{c}4.893 \\
(2.628)\end{array}$ & $\begin{array}{l}10.730^{*} \\
(4.191)\end{array}$ \\
\hline Interaction, islands-Population & $\begin{array}{c}0.000 \\
(0.000)\end{array}$ & $\begin{array}{c}0.000 \\
(0.000)\end{array}$ & $\begin{array}{l}-0.251 \\
(0.244)\end{array}$ & $\begin{array}{l}3.187^{*} \\
(1.410)\end{array}$ & $\begin{array}{l}-0.001 \\
(0.005)\end{array}$ & $\begin{array}{c}0.000 \\
(0.000)\end{array}$ & $\begin{array}{c}0.000 \\
(0.000)\end{array}$ & $\begin{array}{c}0.000 \\
(0.000)\end{array}$ & $\begin{array}{c}0.000 \\
(0.000)\end{array}$ \\
\hline Interaction, islands-Conflicts & $\begin{array}{c}0.001 \\
(1.075)\end{array}$ & $\begin{array}{l}-1.048 \\
(1.406)\end{array}$ & $\begin{array}{l}-0.010 \\
(0.041)\end{array}$ & $\begin{array}{c}0.312 \\
(0.380)\end{array}$ & $\begin{array}{c}44.160 \\
(31.700)\end{array}$ & $\begin{array}{c}0.145 \\
(0.094)\end{array}$ & $\begin{array}{l}-0.058 \\
(0.144)\end{array}$ & $\begin{array}{l}-0.025 \\
(0.130)\end{array}$ & $\begin{array}{c}0.297 \\
(0.310)\end{array}$ \\
\hline Interaction, islands-British & $\begin{array}{l}-3.742 \\
(11.020)\end{array}$ & $\begin{array}{c}8.218 \\
(10.430)\end{array}$ & $\begin{array}{c}0.148 \\
(0.726)\end{array}$ & $\begin{array}{l}-4.392 \\
(3.681)\end{array}$ & $\begin{array}{l}-171.300 \\
(321.900)\end{array}$ & $\begin{array}{l}-0.110 \\
(0.955)\end{array}$ & $\begin{array}{c}0.009 \\
(1.466)\end{array}$ & $\begin{array}{c}0.449 \\
(1.319)\end{array}$ & $\begin{array}{l}-4.044 \\
(3.110)\end{array}$ \\
\hline Island dummy & $\begin{array}{l}35.170^{*} \\
(16.600)\end{array}$ & $\begin{array}{c}16.740 \\
(11.560)\end{array}$ & $\begin{array}{l}-0.462 \\
(1.960)\end{array}$ & $\begin{array}{c}0.399 \\
(10.920)\end{array}$ & $\begin{array}{l}-329.200 \\
(297.800)\end{array}$ & $\begin{array}{l}-2.523^{* *} \\
(0.884)\end{array}$ & $\begin{array}{l}-3.759^{* *} \\
(1.357)\end{array}$ & $\begin{array}{l}-4.339^{* * *} \\
(1.220)\end{array}$ & $\begin{array}{l}-2.830 \\
(3.559)\end{array}$ \\
\hline Isolation & $\begin{array}{c}0.036^{* * *} \\
(0.008)\end{array}$ & $\begin{array}{c}0.031 \\
(0.017)\end{array}$ & $\begin{array}{c}0.000 \\
(0.000)\end{array}$ & $\begin{array}{l}-0.017 \\
(0.010)\end{array}$ & $\begin{array}{l}-0.066 \\
(0.523)\end{array}$ & $\begin{array}{c}0.000 \\
(0.002)\end{array}$ & $\begin{array}{l}-0.002 \\
(0.002)\end{array}$ & $\begin{array}{l}-0.002 \\
(0.002)\end{array}$ & $\begin{array}{l}-0.001 \\
(0.007)\end{array}$ \\
\hline Area & $\begin{array}{l}0.000 \\
(0.000)\end{array}$ & $\begin{array}{l}0.000 \\
(0.000)\end{array}$ & $\begin{array}{l}0.128 \\
(0.072)\end{array}$ & $\begin{array}{c}3.574^{* * * *} \\
(1.014)\end{array}$ & $\begin{array}{l}0.000^{*} \\
(0.000)\end{array}$ & $\begin{array}{c}0.000 * * * \\
(0.000)\end{array}$ & $\begin{array}{l}0.000^{*} \\
(0.000)\end{array}$ & $\begin{array}{c}0.000^{* *} \\
(0.000)\end{array}$ & $\begin{array}{c}0.000 \\
(0.000)\end{array}$ \\
\hline Ethnic fractionalization & 9.403 & $23.210^{* *}$ & -0.146 & -18.240 & $499.900 * *$ & 0.207 & $-1.749^{*}$ & $-2.261 * * *$ & $-3.380^{*}$ \\
\hline & $(6.372)$ & $(8.734)$ & $(0.351)$ & $(5.515)$ & $(161.600)$ & $(0.478)$ & $(0.734)$ & $(0.660)$ & $(1.492)$ \\
\hline Population & $-0.000 * * *$ & $-0.000 *$ & 0.062 & -4.585 & 0.000 & $0.000 * * *$ & $0.000 * *$ & $0.000 * *$ & 0.000 \\
\hline Probability of conflict & $\begin{array}{l}(0.000) \\
-0.076 \\
(0.321)\end{array}$ & $\begin{array}{l}(0.000) \\
-0.418 \\
(0.496)\end{array}$ & $\begin{array}{c}(0.097) \\
-0.007 \\
(0.020)\end{array}$ & $\begin{array}{l}(1.016) \\
-0.278 \\
(0.301)\end{array}$ & $\begin{array}{l}(0.000) \\
-0.799 \\
(8.917)\end{array}$ & $\begin{array}{l}(0.000) \\
0.068^{*} \\
(0.027)\end{array}$ & $\begin{array}{c}(0.000) \\
0.1111^{* *} \\
(0.041)\end{array}$ & $\begin{array}{l}(0.000) \\
0.076^{*} \\
(0.037)\end{array}$ & $\begin{array}{c}(0.000) \\
-0.232^{*} \\
(0.089)\end{array}$ \\
\hline British colony & $\begin{array}{l}-2.828 \\
((3.830)\end{array}$ & $\begin{array}{l}-6.114 \\
(5.515)\end{array}$ & $\begin{array}{c}0.141 \\
(0.246)\end{array}$ & $\begin{array}{l}4.771 \\
(3.019)\end{array}$ & $\begin{array}{l}-29.110 \\
(97.870)\end{array}$ & $\begin{array}{l}-0.310 \\
(0.290)\end{array}$ & $\begin{array}{c}0.112 \\
(0.446)\end{array}$ & $\begin{array}{l}-0.209 \\
(0.401)\end{array}$ & $\begin{array}{l}-0.843 \\
(0.919)\end{array}$ \\
\hline Constant & $\begin{array}{c}-0.0269^{* *} \\
(0.009)\end{array}$ & $\begin{array}{l}-0.025 \\
(0.017)\end{array}$ & $\begin{array}{l}-0.001 \\
(0.001)\end{array}$ & $\begin{array}{c}0.018 \\
(0.010)\end{array}$ & $\begin{array}{c}0.205 \\
(0.552)\end{array}$ & $\begin{array}{c}0.000 \\
(0.002)\end{array}$ & $\begin{array}{c}0.001 \\
(0.003)\end{array}$ & $\begin{array}{c}0.001 \\
(0.002)\end{array}$ & $\begin{array}{l}-0.003 \\
(0.007)\end{array}$ \\
\hline Observations & 144 & 140 & 151 & 143 & 136 & 136 & 136 & 136 & 89 \\
\hline R-squared & 0.464 & 0.325 & 0.180 & 0.320 & 0.187 & 0.456 & 0.382 & 0.429 & 0.434 \\
\hline Number of island states & 35 & 34 & 29 & 35 & 14 & 14 & 14 & 14 & 14 \\
\hline Robust standard errors & yes & no & yes & yes & no & no & no & no & no \\
\hline Population and area logged & no & no & yes & yes & no & no & no & no & no \\
\hline
\end{tabular}

in the Standard errors in parrentheses, $=p<0.001$, 
When focusing on the interaction terms with the island dummy it is evident that there are very few instances where we find significant effects. In fact, we find that in only nine of our dependent variables the variance can to some extent be explained by the interaction terms. Specifically, islands situated closer to the continent seem to exert less damaging pressure on fish stocks on average. Smaller islands tend to have a lower percentage of their area situated in threatened ecoregions and have cleaner coastal waters. However, at the same time they tend to have higher nitrogen loading both in the water and atmosphere. However, on the contrary, islands with larger populations tend to have cleaner coastal waters on average. Ethnic heterogeneity of populations on islands tends to result in lower carbon dioxide emissions per capita and less generation of hazardous waste, while fractionalized island states on average tend to have worse coastal water quality. Finally, island states with a heritage of British colonialism tend to be associated with better access to sanitation. In other words, the six independent factors we study seldom seem to be robust predictors of the variance in the states' performances in these environmental indices and these factors are not especially good at predicting islands' environmental performances in particular.

A limitation of this study deserves mentioning. It should be stated that there are numerous predictors for how states perform in environmental indicators. We have, in the analysis performed in this paper, focused explicitly on the underlying five factors said to make island states perform better in numerous institutional aspects (e.g., democracy and economic development). As such, we have not controlled statistically for potential intermediary variables that might explain states' general performances in the environmental indicators. As stated, this is due to the fact that our aim has not been to explain fully how states perform in these indices, but explicitly to test: (1) if island status has an impact on environmental performance; and (2) if the variables identified as driving the islands' positive performances in other aspects are also important when analyzing their environmental performance. It is likely that an analysis of over 100 dependent variables comes with a cost of nuances and specificity. This article has approached the topic of island states' environmental performances in the broadest sense possible and, hence, might have lost some fine-tuned findings of certain environmental indicators, compared to for instance having only studied one single environmental indicator. It is also worth noting that we cannot fully establish causality relying solely on cross-sectional data. Still, establishing correlation is an important first step in investigating our theoretical arguments, which provide a causal story. To capture the causality, we encourage further research using time series cross-section data.

\section{Concluding Remarks}

This paper takes its point of departure in the issue of coordinating environmentally-related collective action and it has hypothesized that since a growing research field holds that island states show outstanding performance as regards a number of large-scale coordination-related outcomes, we assumed that they may be equally successful in generating environmental collective action.

Compared to continental countries, island states tend to have stronger institutions, higher levels of democracy, better rule of law and more vibrant economic systems. All such outcomes in turn generally depend on the ability to coordinate and overcome collective action problems and social dilemmas. The classical notion of such dilemmas is that since everyone enjoys the benefits from a mutual good-such as rule of law-once they exist, it is rational for each and every individual to free ride and not participate in the joint effort of producing such goods. Furthermore, if individuals expect others to free ride, they themselves will free ride, too. Island states are, however, held to exhibit a number of features making such problems less likely. Their homogeneity in terms of language and ethnicity is argued to result in high levels of social capital and a strong national identity; their distinct colonial history is held to have produced stronger democratic values; their externally given borders are argued to reduce the risk of conflict and stimulate a consensus of values; and their smallness is said to facilitate interactions and transparency in society. All these factors are held to facilitate collective action.

Given these theoretical arguments, as well as the empirical studies indicating that island states, in general, are more successful when it comes to large-scale coordination-related outcomes, it should be expected that island states do comparatively well also in regard to environmental performance. 
Protection of natural resources and the environment is generally held to be a textbook example of a set of actions subjected to various dilemmas and collective action problems and, thus, constitute a hard test of previous theoretical claims. Using a unique dataset of 105 environmental indicators available across countries, we perform the first empirical test of this kind. Second, we test the explanatory power of the previously put forward factors said to explain success in collective action.

It has become clear in the article, however, that the results are rather ambiguous. First, island states are not as successful as could perhaps have been expected. They seem to perform better in some environmental indicators but with no difference from mainland states or even worse, in others. For instance, there is a positive effect from being an island on indicators related to water quality, but a negative one on indicators related to environmental regulations and also numerous measures of protected areas and biodiversity. Hence, in general, it seems that island states are not better at coordinating environmental management than continental states. Second, the explanatory power of the previously put forward factors argued to facilitate collective action is generally low. For some indices, the factors are related to the internal composition of islands, such as their homogeneity. On other indicators, the observed effects seem to stem from geographical factors of territory size, isolation, or their colonial history. For example, smaller islands tend to have cleaner coastal waters; ethnic homogeneity seems to explain a country's performance in carbon dioxide emissions and the generation of waste, while former British colonies seem to have better access to sanitation.

How can we understand these puzzling results? To start with, islands not outcompeting continental states when it comes to environmental performance can plausibly be understood as stemming from the fact that environmental performance is a subject to considerably tougher coordination challenges than other collective action related outcomes: collective-action related to the environment generally has more diffuse payoffs than collective action in other areas. For example, environmental performance highlight complex issues of uncertainty, time horizons, and scale dynamics, which make collective action less likely in the first place and thus substantially more challenging to coordinate.

Second, that the explanatory power of the previously put forward explanatory factors is weaker than expected can plausibly be attributed to some of the assumed positive factors coming with a negative flipside, too. For example, the general smallness of island states might imply that they suffer disproportionately from greater output volatility and greater volatility in terms of trade, which might spur more intense resource exploitation. Small polities might also be more vulnerable to various forms of patronage and political clientelism, and their geographical location and isolation might make them more vulnerable to environmental shocks and natural disasters, which naturally put their natural resources under severe pressure.

In conclusion, this article has contributed to theory and empirical research by providing a detailed comparative analysis of the environmental performance of islands and continental states. Addressing the problem of measuring environmental performance, we have adopted a broad approach, where we analyze over 100 variables related to environmental outcomes. In order to fully grasp why some societies are more successful than others as regards collective action-related to the environment, future research would benefit from addressing not only the underlying features of island states - that is, the factors we focus on in this paper-but the effect from the numerous possible intermediate factors (such as democracy, economic development, and the quality of government institutions) that might determine states' environmental performances.

As the questions for research in this paper are fairly unexplored, we urge other scholars to continue this discussion and gradually complement this approach with more in-depth examinations. For instance, there is a need for a careful analysis of specific policy areas, such as why island states are outperforming continental states in water-related indices. Additionally, historical analysis can be performed in small- $n$ studies investigating why certain island states differ in their environmental performance in comparison to continental states. Future research could also take into account potentially omitted variables from the analysis performed in this paper. For instance, the relationship between island states and their environmental performance and economic development deserves more 
attention in future research. We urge scholars to continue these endeavors with different methods and approaches.

Supplementary Materials: The following are available online at www.mdpi.com/2071-1050/8/3/285/s1, Table S1: The list of environmental indicators used as dependent variables.

Acknowledgments: We thank the Swedish Research Council for generous funding of the project. This paper has been previously presented at the 8th Western Indian Ocean Marine Science Association Symposium and the 13th Nordic Environmental Social Science conference and we would like to thank our panel members for valuable feedback. We are also grateful to anonymous reviewers for many insightful comments, which have considerably improved our manuscript.

Author Contributions: Sverker C. Jagers, Marina Povitkina, Martin Sjöstedt and Aksel Sundström conceived and designed the study; Sverker C. Jagers, Marina Povitkina, Martin Sjöstedt and Aksel Sundström analyzed the data; Sverker C. Jagers, Marina Povitkina, Martin Sjöstedt and Aksel Sundström wrote the paper.

Conflicts of Interest: The authors declare no conflict of interest.

\section{Appendix A. The List of Island States Used in the Analysis}

1. Antigua and Barbuda

2. Bahamas

3. Bahrain

4. Barbados

5. Solomon Islands

6. Cape Verde

7. Sri Lanka

8. Comoros

9. Cuba

10. Cyprus

11. Fiji

12. Kiribati

13. Grenada

14. Iceland

15. Jamaica

16. Japan

17. Madagascar

18. Malta

19. Mauritius

20. Nauru

21. Vanuatu

22. New Zealand

23. Micronesia

24. Marshall Islands

25. Palau

26. The Philippines

27. Saint Kitts and Nevis

28. Saint Lucia

29. Saint Vincent and the Grenadines

30. Seychelles

31. Singapore

32. Tonga

33. Trinidad and Tobago

34. Tuvalu

35. Samoa 
Table A1. The island states included in each model.

\begin{tabular}{|c|c|c|c|c|c|c|c|c|c|c|c|c|c|}
\hline Country Name/Variable Name & $\begin{array}{c}\text { Antigua \& } \\
\text { Barbuda }\end{array}$ & Bahamas & Bahrain & Barbados & $\begin{array}{l}\text { Cape } \\
\text { Verde }\end{array}$ & Comoros & Cuba & Cyprus & Fiji & Grenad & a Iceland & Jamaica & Japan \\
\hline Access to water & + & + & & + & + & + & + & + & & + & + & + & + \\
\hline Access to sanitation & + & + & & + & + & + & + & + & & + & + & + & + \\
\hline Water quality & + & + & + & + & + & + & + & + & + & + & + & + & + \\
\hline Water consumption & & + & & & & & + & + & + & & + & + & + \\
\hline Nitrogen loading & & + & & & & & + & + & + & & + & + & + \\
\hline Urban particulates & + & + & + & + & & + & + & + & + & + & + & + & + \\
\hline Acidification & + & + & + & + & + & + & + & + & + & + & + & + & + \\
\hline $\mathrm{CO}_{2}$ per GDP & + & + & + & + & + & + & + & + & + & + & + & + & + \\
\hline Threatened ecoregions & + & + & + & + & + & + & + & + & + & + & + & + & + \\
\hline Forest cover change & + & + & & + & + & + & + & + & + & + & + & + & + \\
\hline Timber harvest rate & + & & & & + & & + & + & & & + & + & + \\
\hline Fishing pressure & + & + & + & + & + & + & + & + & + & + & + & + & + \\
\hline Overfishing & + & + & + & + & + & + & + & + & + & + & + & + & + \\
\hline Fish catch & + & + & + & + & + & + & + & + & + & + & + & + & + \\
\hline Clean waters & + & + & + & + & + & + & + & + & + & + & + & + & + \\
\hline Water footprint of consumption internal & & + & + & & + & & + & + & + & & + & + & + \\
\hline Water footprint of production-Green water & & + & + & & + & & + & + & + & & + & + & + \\
\hline Water footprint of production-Blue water & & + & + & & + & & + & + & + & & + & + & + \\
\hline Water footprint of production-Return flows & & + & + & & + & & + & + & + & & + & + & + \\
\hline Generation of hazardous waste & & + & + & + & & & + & + & & & + & & + \\
\hline
\end{tabular}


Table A1. Cont.

\begin{tabular}{|c|c|c|c|c|c|c|c|c|c|c|c|c|}
\hline Country Name/Variable Name & Kiribati & Madagascar & Malta & $\begin{array}{c}\text { Marshall } \\
\text { Islands }\end{array}$ & Mauritius & Micronesia & Nauru & $\begin{array}{c}\text { New } \\
\text { Zealand }\end{array}$ & Palau & $\begin{array}{c}\text { The } \\
\text { Philippines }\end{array}$ & Samoa & Seychelles \\
\hline Access to water & + & + & + & + & + & + & & + & + & + & + & \\
\hline Access to sanitation & + & + & + & + & + & + & & & + & + & + & \\
\hline Water quality & & + & + & & + & & & + & & + & + & \\
\hline Water consumption & & + & + & & + & & & + & & + & & \\
\hline Nitrogen loading & & + & + & & + & & & + & & + & & \\
\hline Urban particulates & & + & & & & & & + & & + & & \\
\hline Acidification & + & + & + & + & + & + & + & + & + & + & + & + \\
\hline $\mathrm{CO}_{2}$ per GDP & + & + & + & & + & & & + & + & + & + & + \\
\hline Threatened ecoregions & + & + & + & + & + & + & & + & + & + & + & + \\
\hline Forest cover change & + & + & + & + & + & + & & + & + & + & + & + \\
\hline Timber harvest rate & & + & + & & & & & + & & + & & + \\
\hline Fishing pressure & + & + & + & + & + & + & + & + & + & + & + & + \\
\hline Overfishing & + & + & + & + & + & & + & + & + & + & + & + \\
\hline Fish catch & & + & + & $T_{T}$ & + & & & + & $T^{T}$ & + & + & + \\
\hline Clean waters & + & + & + & + & + & + & + & + & + & + & + & + \\
\hline Water footprint of consumption internal & & + & + & & + & & & & & + & & \\
\hline Water footprint of production-Green water & & + & + & & + & & & & & + & & \\
\hline Water footprint of production-Blue water & & + & + & & + & & & & & + & & \\
\hline Water footprint of production-Return flows & & + & + & & + & & & & & + & & \\
\hline Generation of hazardous waste & & & & & & + & & + & + & & & \\
\hline
\end{tabular}


Table A1. Cont.

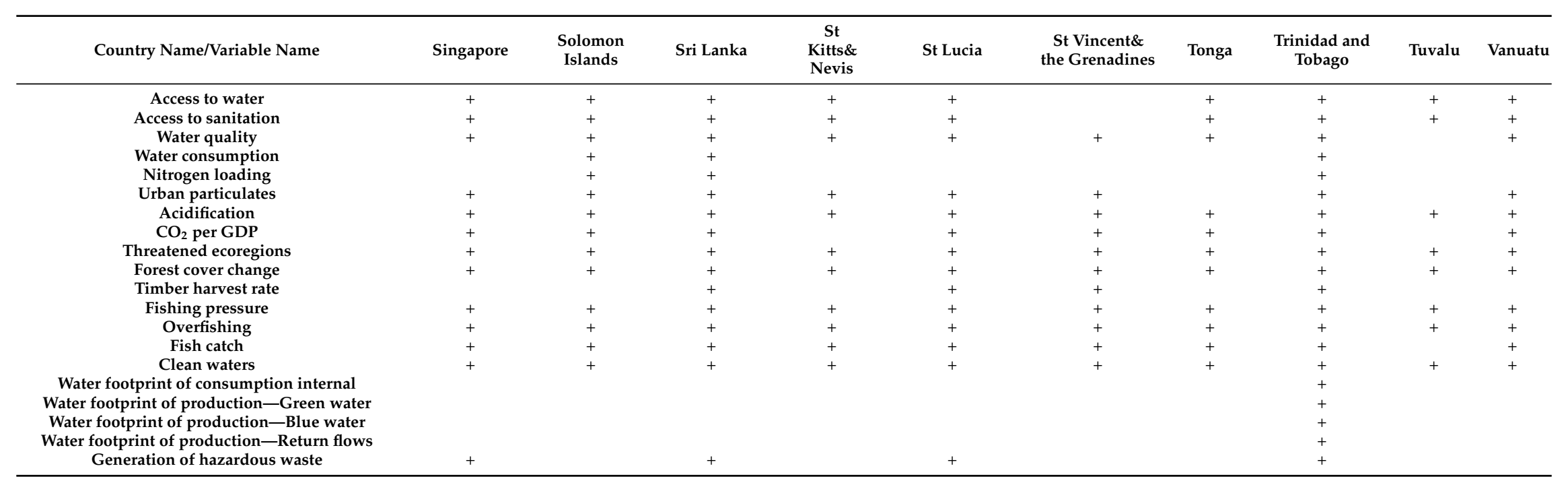




\section{Appendix B. Island States' Performance in the Provision of Environmental Public Goods in Comparison to Continental States}

Table B1. The environmental indices where island status has a significant positive effect (at the 95 per cent confidence interval).

\begin{tabular}{ll}
\hline$\#$ & Name of the Variable \\
\hline Water and Sanitation & \\
\hline 1 & Percent of people with access to improved water supply \\
2 & Percent of people with access to adequate sanitation \\
3 & Change in water quantity \\
4 & Water consumption (proximity to target) \\
5 & Nitrogen loading (proximity to target) \\
\hline $\begin{array}{l}\text { Air and Emissions } \\
6\end{array}$ & Urban particulates (proximity to target) \\
7 & Acidification exceedance from anthropogenic sulfur deposition \\
8 & Carbon dioxide per GDP (proximity to target) \\
\hline $\begin{array}{l}\text { Protected Areas } \\
9\end{array}$ & Percentage of country's territory in threatened ecoregions \\
\hline Forest and Vegetation & \\
10 & Forest cover change \\
11 & Timber harvest rate (proximity to target) \\
\hline Fisheries and the Marine Environment \\
12 & Coastal shelf fishing pressure \\
13 & Overfishing (proximity to target) \\
14 & Fish catch in marine and inland waters \\
15 & Clean waters \\
\hline Ecological Footprint & Water footprint of consumption-Internal \\
16 & Water footprint of production-Green water \\
17 & Water footprint of production-Blue water \\
19 & Water footprint of production-Return flows \\
\hline Waste & Generation of hazardous waste \\
\hline & \\
\hline & \\
\hline
\end{tabular}

Table B2. The environmental indices where island status has a significant negative effect (at the 95 per cent confidence interval).

\begin{tabular}{ll}
\hline Air & \\
\hline 21 & Sulfur dioxide emissions per capita \\
22 & Carbon dioxide per capita \\
23 & Anthropogenic sulfur dioxide emissions per populated land area \\
24 & Anthropogenic volatile organic compound emissions per populated land area \\
25 & Use of ozone depleting substances per land area \\
\hline Biodiversity & Endangered species \\
26 & Threatened native bird species as a percentage of total native species \\
27 & Threatened native species as a percentage of total native mammal species \\
28 & Threatened native reptiles as a percentage of total native reptile species \\
29 & Threatened amphibian species as a percentage of known amphibian species in each country \\
30 &
\end{tabular}


Table B2. Cont.

\begin{tabular}{|c|c|}
\hline \multicolumn{2}{|c|}{ Protected Areas } \\
\hline 31 & Marine protection \\
\hline 32 & Ecoregion protection \\
\hline 33 & Critical habitat protection \\
\hline \multicolumn{2}{|c|}{ Forest } \\
\hline 34 & Percentage of total forest area that is certified for sustainable management \\
\hline \multicolumn{2}{|c|}{ Fisheries and the Marine Environment } \\
\hline 35 & Sense of place-Lasting special places \\
\hline 36 & Tons of fish catch per ton of fish catching capacity \\
\hline 37 & Food provision-Mariculture \\
\hline 38 & Natural products \\
\hline \multicolumn{2}{|c|}{ Energy } \\
\hline 39 & Renewable energy (proximity to target) \\
\hline \multicolumn{2}{|c|}{ Agriculture, Pesticides, Fertilizers } \\
\hline 40 & Fertilizer consumption per hectare of arable land \\
\hline 41 & Pesticide consumption per hectare of arable land \\
\hline 42 & Intensive farming \\
\hline \multicolumn{2}{|c|}{ Land Use } \\
\hline 43 & Fragmented habitats \\
\hline 44 & Percentage of land that is built upon \\
\hline \multicolumn{2}{|c|}{ Water Footprint } \\
\hline 45 & Water footprint of consumption-External \\
\hline \multicolumn{2}{|c|}{ Environmental Regulation } \\
\hline 46 & Number of environmental agreements \\
\hline 47 & Participation in international environmental agreements \\
\hline 48 & Number of memberships in environmental intergovernmental organizations \\
\hline 49 & Participation in the Responsible Care Program of the Chemical Manufacturer's Association \\
\hline \multicolumn{2}{|c|}{ Anthropogenic Pressure } \\
\hline 50 & Percentage of total land area (including inland waters) having very low anthropogenic impact \\
\hline 51 & Percentage of total land area (including inland waters) having very high anthropogenic impact \\
\hline
\end{tabular}

Table B3. The environmental indices where island status did not have any significant effect (at the 95 per cent confidence interval).

\begin{tabular}{ll}
\hline Water and Sanitation \\
\hline 52 & Water withdrawal score \\
\hline Air & \\
53 & Sulfur dioxide emissions per GDP \\
54 & Carbon dioxide emissions per electricity generation \\
55 & Import of polluting goods and raw materials as percentage of total imports of goods and services \\
56 & Use of ozone depleting substances per capita \\
57 & Regional ozone (proximity to target) \\
58 & Anthropogenic NOx emissions per populated land area \\
\hline Biodiversity \\
59 & Threatened flowering plants species as a percentage of all wild species \\
60 & Threatened gymnosperms as a percentage of total native species of gymnosperms \\
61 & Threatened native species of pteridophytes as a percentage of total native species \\
62 & National biodiversity index \\
63 & Extinctions \\
\hline Protected Areas \\
64 & Terrestrial protected areas \\
65 & Wilderness protection (proximity to target) \\
\hline
\end{tabular}


Table B3. Cont.

\begin{tabular}{|c|c|}
\hline \multicolumn{2}{|c|}{ Forest and Vegetation } \\
\hline 66 & Growing stock change \\
\hline 67 & Forest loss \\
\hline 68 & Natural vegetation cover remaining \\
\hline 69 & Loss of natural vegetation cover \\
\hline \multicolumn{2}{|c|}{ Fisheries and the Marine Environment } \\
\hline 70 & Fishing stocks overexploited \\
\hline 71 & Fish catching capacity per fish producing area score \\
\hline 72 & Fishing effort \\
\hline 73 & Percentage of fish species overexploited and depleted \\
\hline 74 & Fisheries protection score \\
\hline 75 & Ecosystem imbalance \\
\hline 76 & Food provision-Wild caught fisheries \\
\hline 77 & Sense of place-Iconic species \\
\hline 78 & Biodiversity-Habitats \\
\hline 79 & Biodiversity-Species \\
\hline 80 & Carbon storage \\
\hline 81 & Coastal protection \\
\hline \multicolumn{2}{|c|}{ Energy } \\
\hline 82 & Energy efficiency (proximity to target) \\
\hline 83 & Energy materials score \\
\hline \multicolumn{2}{|c|}{ Agriculture, Pesticides, Fertilizers } \\
\hline 84 & Salinized area due to irrigation as percentage of total arable land \\
\hline \multicolumn{2}{|c|}{ Land use } \\
\hline 85 & Percentage of cultivated and modified land area with light soil degradation \\
\hline 86 & Percentage of cultivated and modified land area with moderate soil degradation \\
\hline 87 & Percentage of cultivated and modified land area with extreme soil degradation \\
\hline 88 & Degradation \\
\hline 89 & Percentage of modified land \\
\hline 90 & Percentage of land cultivated \\
\hline 91 & Percentage of cultivated and modified land area with strong soil degradation \\
\hline 92 & Desertification sub-index \\
\hline \multicolumn{2}{|c|}{ Ecofootprint } \\
\hline 93 & Water footprint of consumption-total \\
\hline 94 & Water footprint of production-stress on blue water resources \\
\hline 95 & Ecological footprint per capita \\
\hline \multicolumn{2}{|c|}{ Anthropogenic Pressure } \\
\hline 96 & Spills \\
\hline 97 & Mining \\
\hline \multicolumn{2}{|c|}{ Environmental Regulation } \\
\hline 98 & World Economic Forum Survey on environmental governance \\
\hline 99 & Local Agenda 21 initiatives per million people \\
\hline 100 & IUCN member organizations per million population \\
\hline 101 & Number of ISO 14001 certified companies per billion dollars GDP (PPP) \\
\hline 102 & Pesticide regulation \\
\hline 103 & Percentage of variables missing from the CGSDI "Rio to Joburg Dashboard". \\
\hline \multicolumn{2}{|c|}{ Other } \\
\hline 104 & World Economic Forum Survey on private sector environmental innovation \\
\hline 105 & Contribution to international and bilateral funding of environmental projects and development aid \\
\hline
\end{tabular}




\section{References}

1. United Nations. Report of the World Summit on Sustainable Development; A/CONF. 199/20; United Nations Publications: Johannesburg, South Africa, 26 August-4 September 2002.

2. Ostrom, E. Understanding Institutional Diversity; Princeton University Press: Princeton, NJ, USA, 2005.

3. Olson, M. The Logic of Collective Action: Public Goods and the Theory of Groups; Harvard University Press: Cambridge, MA, USA, 1965.

4. Mansbridge, J. The Role of the State in Governing the Commons. Environ. Sci. Policy 2014, 36, 8-10. [CrossRef]

5. Lubell, M.; Zahran, S.; Vedlitz, A. Collective action and Citizen Responses to Global Warming. Polit. Behav. 2007, 29, 391-413. [CrossRef]

6. Barrett, S. Why Cooperate? The Incentive to Supply Global Public Goods; Oxford University Press: Oxford, UK, 2010.

7. Duit, A.; Galaz, V.; Eckerberg, K.; Ebbesson, J. Introduction: Governance, Complexity, and resilience. Glob. Environ. Chang. 2010, 20, 363-368. [CrossRef]

8. Duit, A.; Galaz, V. Governance and complexity - emerging issues for governance theory. Governance 2008, 21, 311-335. [CrossRef]

9. Andersen, S.O.; Sarma, K.M. Protecting the Ozone Layer: the United Nations History; Earthscan Press: London, UK, 2002.

10. Anckar, D. Islandness or smallness? A comparative look at political institutions in small island states. Isl. Stud. J. 2006, 1, 43-54.

11. Briguglio, L. Small island developing states and their economic vulnerabilities. World Dev. 1995, 23, 1615-1632. [CrossRef]

12. Congdon-Fors, H. Do island states have better institutions? J. Comp. Econ. 2014, 42, 34-60. [CrossRef]

13. Convention on Biological Diversity (CBD). 2014. What is Island Biodiversity? Available online: http:/ / www.cbd.int/island/intro.shtml (accessed on 27 March 2014).

14. Mulongoy, K.J.; Webbe, J.; Ferreira, M.; Mittermeier, C. The Wealth of Islands-A Global Call for Conservation; Special Issue of the CBD Technical Series; Convention on Biological Diversity: Montreal, QC, Canada, 2006.

15. United Nations. 2014. The International Year of Small Island Developing States 2014. Available online: www.un.org/en/events/islands2014 (accessed 27 March 2014).

16. Agrawal, A.; Goyal, S. Group size and collective action: Third-party monitoring in common-pool resources. Comp. Polit. Stud. 2001, 34, 63-93. [CrossRef]

17. Grafton, R.Q.; Knowles, S. Social capital and national environmental performance: A cross-sectional analysis. J. Environ. Dev. 2004, 13, 336-370. [CrossRef]

18. Naidu, S.C. Heterogeneity and collective management: Evidence from common forests in Himachal Pradesh, India. World Dev. 2009, 37, 676-686. [CrossRef]

19. Ostrom, E. Governing the Commons; Cambridge University Press: Cambridge, UK, 1990.

20. Emerson, J.W.; Hsu, A.; Levy, M.A.; de Sherbinin, A.; Mara, V.; Esty, D.C.; Jaiteh, M. 2012 Environmental Performance Index and Pilot Trend Environmental Performance Index; Yale Center for Environmental Law and Policy: New Haven, CT, USA, 2012.

21. Anckar, D. Noncontiguity and political architecture: the parliaments of small island states. Polit. Geogr. 1996, 15, 697-713. [CrossRef]

22. Central Intelligence Agency (CIA). 2012. The World Factbook. Available online: https:/ / www.cia.gov/library/publications/the-world-factbook/ (accessed on 10 March 2016).

23. Easterly, W.; Kraay, A. Small states, small problems? Income, growth, and volatility in small states. World Dev. 2000, 28, 2013-2027. [CrossRef]

24. Harden, S. Small is Dangerous: Micro-States in a Macro-World; Frances Pinter: London, UK, 1985.

25. Kuznets, S. Economic Growth of Small Nations. In The Economic Consequences of the Size of Nations: Proceedings of a Conference held by the International Economic Association, 1960; Robinson, E.A.G., Ed.; MacMillan: London, UK, 1960.

26. Armstrong, H.; Read, R. Trade and growth in small states: The impact of global trade liberalizations. World Econ. 1998, 21, 563-585. [CrossRef] 
27. Srinivasan, T.N. The costs and benefits of being a small remote island landlocked or ministate economy. World Bank Res. Obs. 1986, 1, 197-202. [CrossRef]

28. Anckar, D. Direct Democracy in Microstates and Small Island States. World Dev. 2004, 32, 379-390. [CrossRef]

29. Ott, D. Small is Democratic: An Examination of State Size and Democratic Development; Garland: New York, NY, USA, 2000.

30. Clague, C.; Gleason, S.; Knack, S. Determinants of lasting democracy in poor countries: Culture, development, and institutions. Ann. Am. Acad. Polit. Soc. Sci. 2001, 573, 16-41. [CrossRef]

31. Anckar, D.; Anckar, C. Size, insularity and democracy. Scand. Polit. Stud. 1995, 18, 211-229.

32. Baldacchino, G. The contribution of social capital to economic growth in small states: Lessons from island jurisdictions. Round Table Commonw. J. Int. Aff. 2005, 94, 31-46. [CrossRef]

33. Srebrnik, H. Small island nations and democratic values. World Dev. 2004, 32, 329-341. [CrossRef]

34. Hadenius, A. Democracy and Development; Cambridge University Press: Cambridge, UK, 1992.

35. King, R. The Geographical Fascination of Islands. The Development Process in Small Island States; Lockhart, D.G., Ed.; Routledge: London, UK, 1993; pp. 13-37.

36. Lowenthal, D. Social Features. In Politics, Security and Development in Small States; Clarke, C., Payne, T., Eds.; Allen \& Unwin: London, UK, 1987; pp. 26-49.

37. Bray, M. Making Small Practical: The Organization and Management of Ministries of Education in Small States; Commonwealth Secretariat: London, UK, 1991.

38. Anckar, D. Homogeneity and smallness: Dahl and Tufte revisited. Scand. Polit. Stud. 1999, 22, $29-44$. [CrossRef]

39. Etro, F. Political geography. Public Choice 2006, 127, 329-351. [CrossRef]

40. Axelrod, R. The Evolution of Cooperation; Basic Books: New York, NY, USA, 1984.

41. Duit, A. Patterns of environmental collective action: Some cross-national findings. Polit. Stud. 2011, 59, 900-920. [CrossRef]

42. Bromley, D.W. Making the Commons Work. Theory, Practice, and Policy; Institute for Contemporary Studies: San Francisco, CA, USA, 1992.

43. Rothstein, B. Social Traps and the Problem of Trust; Cambridge University Press: Cambridge, UK, 2005.

44. Sjöstedt, M. Horizontal and vertical resource dilemmas in natural resource management: The case of African fisheries. Fish Fish. 2013, 14, 616-624. [CrossRef]

45. Duit, A.; Hall, O.; Mikusinski, G.; Angelstam, P. Saving the woodpeckers: Social capital, governance, and policy performance. J. Environ. Dev. 2009, 18, 42-61. [CrossRef]

46. Poteete, A.R.; Ostrom, E. Heterogeneity, group size and collective action: The role of institutions in forest management development and change. Dev. Chang. 2004, 35, 435-461. [CrossRef]

47. Erdlenbruch, K.; Tidball, M.; van Soest, D. Renewable resource management, user heterogeneity, and the scope for cooperation. Ecol. Econ. 2008, 64, 597-602. [CrossRef]

48. Agrawal, A.; Gibson, C. Enchantment and disenchantment: The role of community in natural resource conservation. World Dev. 1999, 27, 629-649. [CrossRef]

49. Firmin-Sellers, K. The politics of property rights. Am. Polit. Sci. Rev. 1995, 89, 867-881. [CrossRef]

50. Ostrom, E. Coping with the tragedies of the commons. Annu. Rev. Polit. Sci. 1999, 2, 493-535. [CrossRef]

51. Pelling, M.; Uitto, J.I. Small island developing states: Natural disaster vulnerability and global change. Environ. Hazards 2001, 3, 49-62.

52. United Nations. Programme of Action for the Sustainable Development of Small Island Developing, States-A/CONF.167/9 Chapter I, Annex II. 2005. Collapse: How Societies Choose to Fail or Succeed Viking; Diamond, J.M., Ed.; United Nations Publications: New York, NY, USA, 1994.

53. Baldacchino, G. Global Tourism and Informal Labour Relations: The Small-Scale Syndrome at Work; Mansell: London, UK, 1997.

54. Veenendaal, W.P. Democracy in microstates: why smallness does not produce a democratic political system. Democratization 2015, 22, 92-112. [CrossRef]

55. Bell, S.; Morse, S. Sustainability Indicators: Measuring the Immeasurable; Earthscan: London, UK, 1999.

56. Parris, T.M.; Kates, R.W. Characterizing and measuring sustainable development. Ann. Rev. Environ. Resour. 2003, 28, 559-586. [CrossRef] 
57. Hammond, A.; Adriaanse, A.; Rodenburg, E.; Bryant, D.; Woodward, R. Environmental Indicators: A Systematic Approach to Measuring and Reporting on Environmental Policy Performance in the Context of Sustainable Development; World Resources Institute: Washington DC, USA, 1995.

58. Smeets, E.; Weterings, R. Environmental Indicators: Typology and Overview; (European Environmental Agency, Technical Reports no. 25); European Environmental Agency: Copenhagen, Denmark, 1999.

59. Cole, M.A. Corruption, income and the environment: An empirical analysis. Ecol. Econ. 2007, 62, $637-647$. [CrossRef]

60. Koyuncu, C.; Yilmaz, R. The impact of corruption on deforestation: Cross-country evidence. J. Dev. Areas 2009, 42, 213-222. [CrossRef]

61. Barrett, C.B.; Gibson, C.C.; Hoffman, B.; McCubbins, M.D. The complex links between governance and biodiversity. Conser. Biol. 2006, 20, 1358-1366. [CrossRef] [PubMed]

62. Center for International Earth Science Information Network-CIESIN-Columbia University. Compendium of Environmental Sustainability Indicator Collections: Ancillary Data. Palisades, NY: NASA Socioeconomic Data and Applications Center (SEDAC). Available online: http://dx.doi.org/10.7927/H4B56GNC (accessed on 7 September 2013).

63. Kaly, U.L.; Pratt, C.R.; Mitchell, J. The Environmental Vulnerability Index (EVI) 2004. Available online: http:/ / www.sopac.org/sopac/evi/Files/EVI2004TechnicaReport.pdf (accessed on 9 September 2013).

64. Alesina, A.; Devleeschauwer, A.; Easterly, W.; Kurlat, S.; Wacziarg, R. Fractionalization. J. Econ. Growth 2003, 8, 94-155. Available online: http://www.anderson.ucla.edu/faculty_pages/ romain.wacziarg/downloads/fractionalization.xls (accessed on 9 September 2013). [CrossRef]

65. Central Intelligence Agency. The World Factbook 2013-2014. Available online: https://www.cia.gov/ library/publications/the-world-factbook/ (accessed on 7 September 2013).

66. Guha-Sapir, D.; Below, R.; Hoyois, P.H. EM-DAT: The CRED/OFDA International Disaster Database. Available online: http:/ /www.emdat.be (accessed on 7 September 2013).

67. Teorell, J.; Hadenius, A. Determinants of Democratization: Taking Stock of the Large-N Evidence; Mimeo, Department of Government: Uppsala University, Uppsala, Sweden, 2005.

68. Wooldridge, J.M. Introductory Econometrics: A Modern Approach; Thomson/South-Western: Mason, $\mathrm{OH}$, USA, 2012. 